\title{
Influence of Typhoons on Chemical Makeup of Rainwater in Zhanjiang, China
}

Aerosol and Air Quality Research

\section{OPEN ACCESS}

Received: October 2, 2021

Revised: December 9, 2021

Accepted: January 16, 2022

${ }^{*}$ Corresponding Author:

fjchen@gdou.edu.cn

\section{Publisher:}

Taiwan Association for Aerosol Research

ISSN: $1680-8584$ print

ISSN: 2071-1409 online

cc) Copyright: The Author(s). This is an open access article distributed under the terms of the Creative Commons Attribution License (CC BY 4.0), which permits unrestricted use, distribution, and reproduction in any medium, provided the original author and source are cited.

\author{
Zhen Zeng ${ }^{1}$, Xin Zhou ${ }^{2,3}$, Zhiyang Li ${ }^{4}$, Fajin Chen ${ }^{2,3^{*}}$, Huijie Luo ${ }^{2,3}$, Guirong $\mathrm{He}^{2,3}$, \\ Ziyun Deng ${ }^{2,3}$, Chunqing Chen ${ }^{2,3}$, Qibin Lao ${ }^{2,3}$ \\ ${ }^{1}$ College of Fisheries, Guangdong Ocean University, Zhanjiang 524088, China \\ ${ }^{2}$ College of Ocean and Meteorology, Guangdong Ocean University, Zhanjiang 524088, China \\ ${ }^{3}$ Key Laboratory of Climate, Resources and Environment in Continental Shelf Sea and Deep Sea \\ of Department of Education of Guangdong Province, Guangdong Ocean University, Zhanjiang \\ 524088, China \\ ${ }^{4}$ Guangdong AIB Polytechnic College, Guangzhou 551507, China
}

\section{ABSTRACT}

Typhoons are extreme weather events with substantial effects on ambient air. However, whether typhoons of different intensities have the same effects on the chemical composition of rainwater is unclear. Therefore, 4 years of rainwater sampling and an analysis of the ionic composition $\left(\mathrm{Cl}^{-}, \mathrm{Ca}^{2+}, \mathrm{Na}^{+}, \mathrm{SO}_{4}{ }^{2-}, \mathrm{Mg}^{2+}, \mathrm{F}^{-}\right.$, and $\mathrm{K}^{+}$) of rainwater were conducted in Zhanjiang, a city on the southern tip of mainland China. The ionic composition varied seasonally, being high in dry seasons whereas low in wet seasons; ion levels were controlled by rainfall dilution effects rather than by the monsoon transition. Source determination demonstrated that the marine influences in the dry and wet seasons were similar, further indicating the limited impact of the monsoon climate on the ionic species' seasonal patterns. The heavy rain and strong wind $\left(>47.4 \mathrm{~m} \mathrm{~s}^{-1}\right)$ brought by a super typhoon led to an increase in ionic species carried from continental sources into ambient air, and such species were then captured by precipitation. The weak winds (10.71$12.84 \mathrm{~m} \mathrm{~s}^{-1}$ ) brought by weak typhoons failed to blow such ions into the air, but rainfall dilution still occurred and was dependent upon rainfall amount. Our results suggest that strong typhoons can increase ion concentrations in rainwater, whereas weak typhoons reduce such concentrations. The results provide new insight into the relationship between air quality and typhoons.

Keywords: Wet deposition, Chemical composition, Typhoon intensity, Wind speed, Southern China

\section{INTRODUCTION}

Wet deposition is an essential pathway to scavenge pollutants from atmosphere (Qu et al., 2021). Over $90 \%$ of the total amount of pollutants present in the atmosphere can be scavenged through wet deposition (MacDonald et al., 2018; Mehr et al., 2019; Gromping et al., 1997). The precipitation scavenging comprises two microphysical processes, including the incorporation of gases and particulate matters into existing droplets and the activation of particulate matters to form cloud droplets (MacDonald et al., 2018; Mehr et al., 2019). The chemical composition of rainwater changes with the dissolution of pollutants; therefore, analyzing the chemical makeup of rainwater can be an indirect approach for measuring pollution levels (Al-Khashman, 2005a; Huang et al., 2008a; Liyandeniya et al., 2020). Thus, rainwater composition can be used to predict atmospheric air quality.

Rainwater's composition depends on the atmospheric environment (e.g., gaseous and particulate matter), which is directly associated with local emission levels, weather conditions, drop sizes, and the long-term transport of pollutants with natural or anthropogenic sources (Baron et al., 1993; Migliavacca et al., 2005; Lu et al., 2011; Gioda et al., 2013; Pye et al., 2020; Qu et al., 2021). The effects of pollutant sources on the rainwater chemistry in numerous regions have been 
reported. For example, at an industrial coastal site in Iran, almost all $\mathrm{NO}_{3}{ }^{-}$and most $\mathrm{Ca}^{2+}, \mathrm{Mg}^{2+}$, and $\mathrm{SO}_{4}{ }^{2-}$ were from local sources, and marine emissions were negligible (Rastegari et al., 2019). The effect of natural and urban emissions on precipitation chemistry were investigated at Iran coastal area, and found that nearly all $\mathrm{NO}_{3}{ }^{-}$and most $\mathrm{Ca}^{2+}, \mathrm{Mg}^{2+}$, and $\mathrm{SO}_{4}{ }^{2-}$ were originated from non-marine and local sources, and the four main pollutants sources influencing the regional precipitation were combustion processes, soil, local industrial sources and marine emissions (Mehr et al., 2019). At a semirural site in central China, the annual $\mathrm{pH}$ value, expressed as a volumeweighted mean (VWM), is 4.38; this value was attributed to an insufficient capacity to neutralize $\mathrm{Ca}^{2+}$, which was caused by major anthropogenic pollution (Li et al., 2016). In addition, acidic deposition has adversely influenced most areas in China, Europe and the North United State (Budhavant et al., 2009; Dadashazar et al., 2019; Qu et al., 2021; Sorooshian et al., 2013), and some studies in Asia found that $\mathrm{NO}_{3}{ }^{-}$and $\mathrm{SO}_{4}{ }^{2-}$ were dominant acidifying agents of precipitation, originating mainly from anthropogenic sources (Cao et al., 2009; Kumar et al., 2014; Qu et al., 2021).

Typhoons are one of the most damaging types of natural disasters with their strong winds and heavy rainfall, causing substantial damage to the affected areas (Miao and Chen, 2010; Qin et al., 2020; Souri et al., 2020; Zhou et al., 2021). Typhoons have a major effect on the chemical makeup of atmospheric aerosols; they can carry considerable rainwater volumes containing chemical ions (Mehr et al., 2019; Spracklen et al., 2018; Su et al., 2018; Yan et al., 2016). Previous research has revealed that, when a typhoon passes, some chemical components are transported with typhoon to the area, whereas other components are scavenged by rainfall brought by typhoon (Fang et al., 2009; Sakihama and Tokuyama, 2005; Yan et al., 2016). At a coastal site on Okinawa, the concentrations of non-sea salt $\mathrm{SO}_{4}{ }^{2-}$ and sea salt $\mathrm{SO}_{4}{ }^{2-}$ in rainwater were affected by the maximal wind speed of typhoons, and $\mathrm{pH}$ levels during typhoon periods were lower than those during nontyphoon periods (Sakihama and Tokuyama, 2005). Thus, typhoons drastically change rainwater's chemical components. Zhanjiang, which is located on the north coast of the South China Sea, has a subtropical climate controlled by the East Asian monsoon. In the city, the agricultural productivity, industry and population have increased significantly, which resulting in the air quality is under great pressure (Chen et al., 2019, 2020; Zhou et al., 2021). In addition, the city is frequently affected by typhoon events (Chen et al., 2019, 2020, 2021). The typhoon generally brought heavy rainfall in the rainy seasons, and the typhoon events couple with the East Asian summer monsoon could great impact on the rainwater's chemical composition in the city. However, under such complex meteorological conditions, few studies have investigated the link between typhoons and the chemical makeup of rainwater in Zhanjiang. Therefore, 38 typhoon events that indirectly or directly affected Zhanjiang were investigated. Furthermore, the major ionic components of rainwater during periods in which typhoons directly or indirectly affected Zhanjiang were measured and investigated. The results elucidate the impact of typhoons with different intensities on the atmospheric quality of Zhanjiang.

\section{METHODS}

\subsection{Research Location}

Zhanjiang $\left(20.00^{\circ}-21.58^{\circ} \mathrm{N}, 109.52^{\circ}-110.92^{\circ} \mathrm{E}\right)$, which is situated near the southernmost point of mainland China, is adjacent to the coastal area of northern South China Sea (Fig. 1) and has an area of $13,263 \mathrm{~km}^{2}$. Zhanjiang's tropical climate is controlled by the East Asian monsoon; Zhanjiang's average annual temperature is $23^{\circ} \mathrm{C}$, and it receives average annual precipitation of $1,689 \mathrm{~mm}$ (http://data.cma.cn/). During summer the weather is hot and humid, and the volume of precipitation increases substantially; however, during winter the weather is cool and dry (Chen et al., 2019, 2021). Typhoons are predominant during the summer monsoon, and typhoons over southern China often affect Zhanjiang. Typhoons in the region are the most prevalent from June to October, generally form in the Western Pacific and the South China Sea. The typhoons can bring large amounts of remote moisture and precipitation to the city from the Western Pacific and South China (Hideaki and Akira, 2005; Liu, 2007; Chen et al., 2021).

Recently, Zhanjiang has witnessed rapid growth in its economy, industry (e.g., construction), and population. The population grew from around 5.4 million in 1990 to 7.2 million in 2015. Zhanjiang's main source of power, coal combustion, grew markedly, from the production $9.41 \times 10^{9} \mathrm{~kW} \mathrm{~h}$ in 


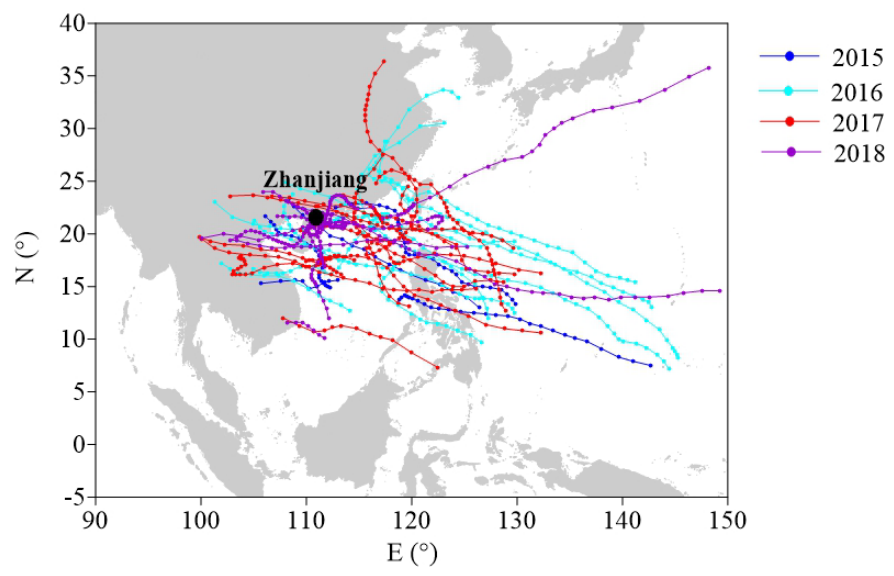

Fig. 1. Zhanjiang (black dot) sampling site and the typhoon paths from 2015 to 2018 (https://tcdata.typhoon.org.cn).

2015 to that of $16.46 \times 10^{9} \mathrm{~kW} \mathrm{~h}$ in 2017 (Chen et al., 2019). Furthermore, the area dedicated to construction in Zhanjiang also rose rapidly from $1938 \times 10^{4} \mathrm{~m}^{2}$ in 2010 to $5243 \times 10^{4} \mathrm{~m}^{2}$ in 2019 , and the number of vehicles increased from $14.9 \times 10^{4}$ in 2010 to $67.6 \times 10^{4}$ in 2019 (Zhanjiang Bureau of Statistics, http://zhanjiang.gov.cn). These data indicate that the city faces potential increases in atmospheric pollution.

\subsection{Sampling and Ionic Composition Analysis}

Rainwater was collected from May 2015 to April 2019 at a sampling location $\left(21.1433^{\circ} \mathrm{N}\right.$, $110.3133^{\circ} \mathrm{E}$ ) in Zhanjiang (Fig. 1). In this study, we defined the period from May 2015 to April 2016 as 2015 , and so on. Rainwater was collected from the beginning to the end of each precipitation event in an acid-washed polyethylene bucket (diameter, $80 \mathrm{~cm}$ ) placed at the sampling site (Chen et al., 2019, 2020). After rainwater collection, the samples were filtered through a glass filter (GF/F, Whatman) and stored in polyethylene bottles at $-20^{\circ} \mathrm{C}$. During the sampling period, 328 samples were collected: 63 in 2015, 68 in 2016, 78 in 2017, 109 in 2018, and 10 in 2019. Because of small $(<0.5 \mathrm{~mm})$ rainfall volumes and drought, no rainwater samples were collected during some months (Chen et al., 2019).

The rainwater samples collected were separated into two aliquots. The first was used for anion detection, and the second, which was acidified using ultrapure nitric acid $(\mathrm{pH}<2)$, was used for cation detection. The levels of principal anions $\left(\mathrm{F}^{-}, \mathrm{SO}_{4}{ }^{2-}\right.$, and $\left.\mathrm{Cl}^{-}\right)$were determined through ionic chromatography (Thermo Dionex Aquion, US), and the levels of principal cations $\left(\mathrm{Mg}^{2+}, \mathrm{Na}^{+}, \mathrm{K}^{+}\right.$, and $\mathrm{Ca}^{2+}$ ) were measured through inductively coupled plasma mass spectrometry (Agilent 7500cx, US). Procedural blanks and a reagent were used alongside the sample treatment; analytical precision superior to $\pm 5 \%$ was achieved.

Al-Khashman (2005b) reported that the ratio of anions to cations indicates completeness of the measured major constituents; when this ratio is $1 \pm 0.25$, the measured data are regarded as acceptable (Keene et al., 1986). The current study's ratio of 0.87 indicated that most major ions collected samples had been identified and measured.

\section{RESULTS}

Fig. 2 presents the average yearly distributions (\%) of ionic species in rainwater. The highest volume-weighted mean (VWM) concentration in rainwater was that for $\mathrm{Cl}^{-}$, followed in order by the concentrations of $\mathrm{Ca}^{2+}, \mathrm{Na}^{+}, \mathrm{SO}_{4}{ }^{2-}, \mathrm{Mg}^{2+}, \mathrm{K}^{+}$, and finally $\mathrm{F}^{-}$. As shown in Fig. 2, the most concentrated ion was $\mathrm{Cl}^{-}$, which had a VWM of $99.3 \mu \mathrm{Eq} \mathrm{L}^{-1}$ and accounted for $35.2 \%$ of detected ions. The VWMs of $\mathrm{Na}^{+}$and $\mathrm{Ca}^{2+}$ were respectively 34.4 and $94.2 \mu \mathrm{Eq} \mathrm{L}^{-1}$, accounting for $12.2 \%$ and $33.5 \%$ of the detected ions. The $\mathrm{K}^{+}$and $\mathrm{F}^{-}$levels were low (accounting for $3.2 \%$ and $1.8 \%$, respectively), with $\mathrm{VWM}$ concentrations of 5.11 and $8.92 \mu \mathrm{Eq} \mathrm{L}^{-1}$, respectively. 


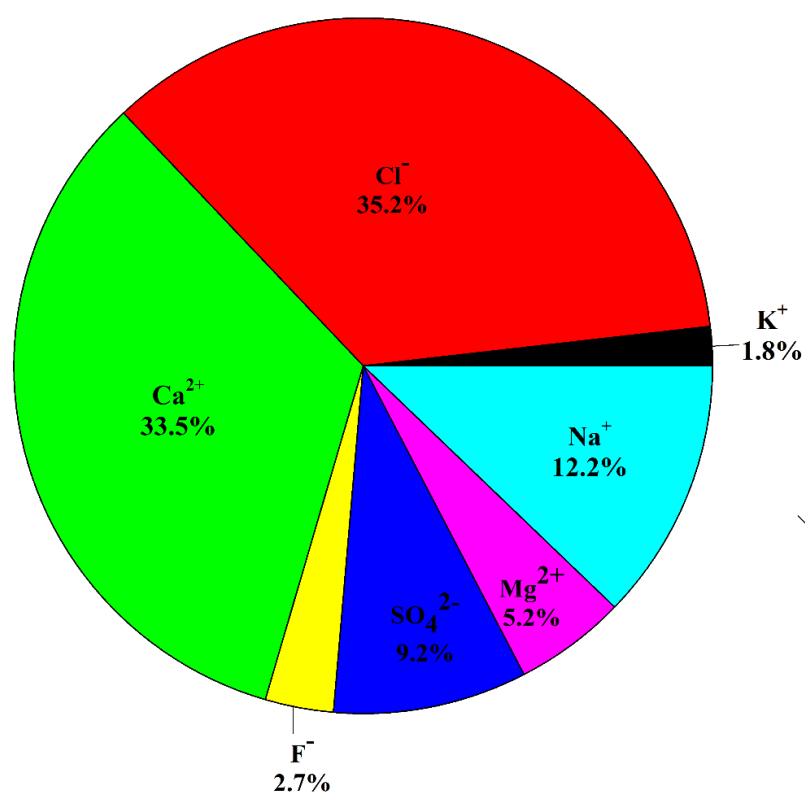

Fig. 2. Chemical makeup (\%) of rainwater in Zhanjiang.

A distinct variation in levels of ionic species was noted between the wet and dry seasons (Fig. 3). The levels of the detected ions were high in the dry seasons and low in the wet seasons. This trend was opposite to that of rainfall (Fig. 3).

\section{DISCUSSION}

\subsection{Temporal Changes in Ionic Species in Rainwater Associates with Rainfall Volume}

lonic species in rainwater in Zhanjiang varied seasonally, being lower and higher in the wet and dry seasons, respectively (Fig. 3). This phenomenon was probably due to the dilution effects of rainfall or clean oceanic air parcels during the summer monsoon (Chen et al., 2019, 2021). However, these seasonal patterns appear likely to be primarily caused by the dilution effects of rainfall rather than monsoon transition as discussed below. During the winter monsoon, the ambient air of Zhanjiang was markedly influenced by air parcels from polluted areas of northwestern China, whereas the air quality in Zhanjiang during the summer monsoon was mainly affected by clean oceanic air parcels (Chen et al., 2019, 2021). This seasonal pattern may lead to considerable wet deposition of ionic species in dry seasons and little wet deposition in wet seasons. The wet ionic deposition in Zhanjiang in the wet seasons was approximately twice that in the dry seasons, indicating that the influence of air parcel transitions (i.e., from the winter monsoon to summer monsoon) was minor. Ion levels were significantly correlated with each other, and most ion levels were negatively correlated with rainfall volume (Table 1 ). These results demonstrate that major ionic species undergo similar processes, suggesting the dilution effects of rainfall to be the primary explanation of low ion levels. Our previous study suggested that rainfall influences temporal changes in the concentration of nitrate and isotopic compositions of nitrate in rainwater (Chen et al., 2019).

$\mathrm{Cl}^{-}$levels, which were higher in coastal areas with considerable wet deposition, may be affected by the maritime factors (e.g., the high sea salt concentration) (Valappil et al., 2020). $\mathrm{Na}^{+}$ is derived from the marine environment and serves as an indicator of oceanic influences (Keene et al., 1986). Zhanjiang, situated on the South China Sea, has a wet coastal climate, and its air is rich in sea salt. Zhanjiang's moisture sources include the Indian Ocean, South China Sea, and western North Pacific Ocean (Chen et al., 2019). In the current study, $\mathrm{Na}^{+}$concentrations in Zhanjiang's rainwater were higher than those in inland (Table 2) and coastal areas (Table 2), and the $\mathrm{Cl}^{-}$concentration in Zhanjiang rainwater was much higher than that in such areas (Table 2); 

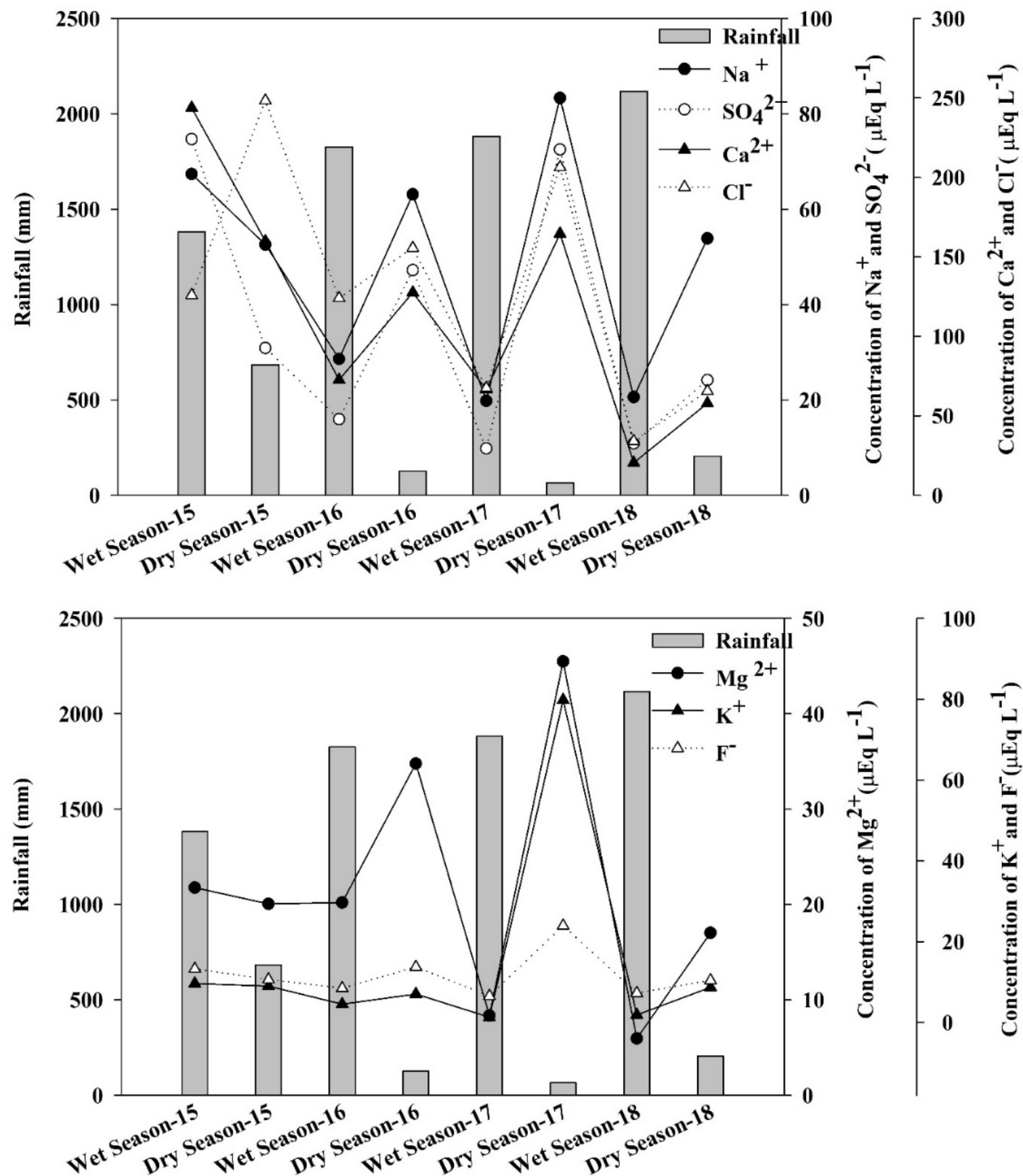

Fig. 3. Seasonal variation in major ions $\left(\mathrm{Cl}^{-}, \mathrm{Ca}^{2+}, \mathrm{Na}^{+}, \mathrm{SO}_{4}{ }^{2-}, \mathrm{Mg}^{2+}, \mathrm{F}^{-}, \mathrm{K}^{+}\right)$and rainfall (gray bars) from 2015 to 2018 in Zhanjiang.

Table 1. Correlation matrix of ionic species in rainwater with rainfall.

\begin{tabular}{|c|c|c|c|c|c|c|c|c|}
\hline & Rainfall & $\mathrm{Mg}^{2+}$ & $\mathrm{K}^{+}$ & $\mathrm{Na}^{+}$ & $\mathrm{Ca}^{2+}$ & $\mathrm{F}^{-}$ & $\mathrm{Cl}^{-}$ & $\mathrm{SO}_{4}{ }^{2-}$ \\
\hline Rainfall & 1 & $-0.545^{* *}$ & -0.300 & $-0.476 * *$ & -0.071 & $-0.504^{* *}$ & $-0.382^{*}$ & -0.293 \\
\hline $\mathrm{Mg}^{2+}$ & & 1 & $0.674^{* *}$ & $0.887^{* *}$ & $0.535^{* *}$ & $0.819^{* *}$ & $0.773^{* *}$ & $0.762^{* *}$ \\
\hline $\mathrm{K}^{+}$ & & & 1 & $0.382^{*}$ & $0.385^{*}$ & $0.853^{* *}$ & $0.458^{* *}$ & $0.590^{* *}$ \\
\hline $\mathrm{Na}^{+}$ & & & & 1 & $0.420^{* *}$ & $0.600^{* *}$ & $0.673^{* *}$ & $0.636^{* *}$ \\
\hline $\mathrm{Ca}^{2+}$ & & & & & 1 & $0.561^{* *}$ & $0.565^{* *}$ & $0.875^{* *}$ \\
\hline $\mathrm{F}^{-}$ & & & & & & 1 & $0.589^{* *}$ & $0.814^{* *}$ \\
\hline $\mathrm{Cl}^{-}$ & & & & & & & 1 & $0.576^{* *}$ \\
\hline $\mathrm{SO}_{4}{ }^{2-}$ & & & & & & & & 1 \\
\hline
\end{tabular}

Note: ${ }^{*} p<0.05 ; * * p<0.01$. 
Table 2. Ionic concentrations $\left(\mu \mathrm{Eq} \mathrm{L^{-1 }}\right)$ in Zhanjiang and other areas of China.

\begin{tabular}{llllllllll}
\hline Area & $\mathrm{K}^{+}$ & $\mathrm{Cl}^{-}$ & $\mathrm{Ca}^{2+}$ & $\mathrm{F}^{-}$ & $\mathrm{SO}_{4}{ }^{2-}$ & $\mathrm{Mg}^{2+}$ & $\mathrm{Na}^{+}$ & $\mathrm{Cl}^{-} / \mathrm{Na}^{+}$ & Reference \\
\hline $\begin{array}{l}\text { Inland area } \\
\quad \text { Guiyang }\end{array}$ & 11.1 & 9.8 & 218 & $/$ & 238 & 18.6 & 1.8 & 5.44 & Lu et al. (2017) \\
$\quad$ Sichuan province & 11.6 & 20.0 & 139 & 10.4 & 201 & 24.8 & 23.8 & 0.84 & Li et al. (2019) \\
$\quad$ Lanzhou & 7.26 & 27.9 & 886 & $/$ & 208 & 46.5 & 12.3 & 2.27 & Xu et al. (2009) \\
$\quad$ Beijing & 9.20 & 50.9 & 273 & 12.0 & 357 & 53.3 & 21.5 & 2.34 & Xu and Han (2009) \\
$\quad$ Xi'an & 13.8 & 38.7 & 426 & 28.7 & 490 & 36.6 & 31.1 & 1.24 & Lu et al. (2011) \\
Coastal area & & & & & & & & & This study \\
$\quad \begin{array}{l}\text { Zhanjiang } \\
\quad \text { Shenzhen }\end{array}$ & 5.11 & 99.3 & 94.2 & 8.92 & 25.3 & 14.6 & 34.4 & 2.89 & Huang et al. (2008b) \\
$\quad$ Shanghai & 1.80 & 20.6 & 35.4 & 1.70 & 64.7 & 3.30 & 11.2 & 1.84 & Huang et al. (2008a) \\
$\quad$ Guangzhou & 14.9 & 58.3 & 204 & 11.0 & 200 & 29.6 & 50.1 & 1.16 & Huang et al. (2009) \\
$\quad$ Jiaozhou & 9.00 & 21.0 & 131 & 12.0 & 202 & 9.00 & 18.0 & 1.17 & Xing et al. (2017) \\
\hline
\end{tabular}

Note: / not presented in the literature.

this can be attributed to the evaporation of seawater from the surrounding basins (Al-Obaidy and Joshi, 2006; Khoon et al., 2011; Valappil et al., 2020; Chen et al., 2019). However, the ratio of Cl to $\mathrm{Na}^{+}$in rainwater at the study site was higher than the same ratios reported for seawater (1.16; Keene et al., 1986) and for rainwater in other coastal areas (Table 2), suggesting that the excess $\mathrm{Cl}^{-}$in this study was derived from coal combustion (Keene et al., 1986; Tang et al., 2006; Xu et al., 2017). $\mathrm{SO}_{4}{ }^{2-}$ was the anion with the second highest abundance, possibly because of the substantial $\mathrm{SO}_{2}$ emitted in the burning of fossil fuel (Qiao et al., 2015). The $\mathrm{SO}_{4}{ }^{2-}$ concentrations in rainwater in Zhanjiang were lower than those in more developed inland areas and megacities (e.g., Guangzhou, Shenzhen, and Shanghai), indicating a weaker influence of fossil fuel combustion (Table 2; Tang et al., 2006). Therefore, human activity (coal combustion) had a stronger influence on the ions in rainwater in Zhanjiang than did marine emissions.

To further demonstrate that the influence of marine emissions was limited and that temporal changes in ionic species were predominantly regulated by rainfall amount, the marine contributions were quantified using Eq. (1) (Xu et al., 2017):

$\mathrm{X}_{\mathrm{ss}}=\mathrm{Na}^{+}{ }_{\mathrm{i}} \times\left(\mathrm{X} / \mathrm{Na}^{+}\right)_{\text {sea }}$

where $\mathrm{X}_{\mathrm{sS}}$ represents the concentrations of $\mathrm{Cl}^{-}, \mathrm{Ca}^{2+}, \mathrm{SO}_{4}{ }^{2-}, \mathrm{Mg}^{2+}$, and $\mathrm{K}^{+}$contributed by sea salt (ss); $\mathrm{Na}^{+}{ }_{i}$ is the $\mathrm{Na}^{+}$concentration in rainwater samples; and $\left(\mathrm{X} / \mathrm{Na}^{+}\right)_{\text {sea }}$ represents the ratio of ion to $\mathrm{Na}^{+}$, which were $1.16,0.0439,0.121,0.227$, and 0.0218 for $\mathrm{Cl}^{-}, \mathrm{Ca}^{2+}, \mathrm{SO}_{4}{ }^{2-}, \mathrm{Mg}^{2+}$, and $\mathrm{K}^{+}$to $\mathrm{Na}^{+}$, respectively (Keene et al., 1986). Table 3 presents the marine effects on ionic species in rainwater in Zhanjiang. Marine influences in wet seasons were comparable to those in dry seasons, indicating that air parcels from the ocean (summer monsoon) and polluted areas of northwestern China (winter monsoon) have little effect on the ionic species in rainwater. Therefore, seasonal variations in ionic species are controlled primarily by rainfall amount.

The dominant cation in rainwater was $\mathrm{Ca}^{2+}$, with a yearly VWM of $94.4 \mu \mathrm{Eq} \mathrm{L}^{-1}$. This finding is comparable to those reported for Xi'an (Lu et al., 2011), Guangzhou (Huang et al., 2009), and Shanghai (Huang et al., 2008a). Mouli et al. (2005) reported that, in general, $\mathrm{Ca}^{2+}$ is produced through mineral aerosol dissolution. Anthropogenic activity (such as intense urban construction activities Zhou et al., 2019) is another source of $\mathrm{Ca}^{2+}$ entering the atmosphere (Li et al., 2019). Recently, the construction industry has grown rapidly in Zhanjiang, with the area dedicated to construction increasing from $1938 \times 10^{4} \mathrm{~m}^{2}$ in 2010 to $5243 \times 10^{4} \mathrm{~m}^{2}$ in 2019 (Zhanjiang Bureau of

Table 3. Marine effects on ionic species in rainwater in Zhanjiang (annual average, unit: \%).

\begin{tabular}{llllll}
\hline & $\mathrm{Mg}^{2+}$ & $\mathrm{K}^{+}$ & $\mathrm{Ca}^{2+}$ & $\mathrm{Cl}^{-}$ & $\mathrm{SO}_{4}{ }^{2-}$ \\
\hline Wet seasons & 56.4 & 14.8 & 3.1 & 48.8 & 21.2 \\
Dry seasons & 56.4 & 22.8 & 3.0 & 48.5 & 26.8 \\
\hline
\end{tabular}




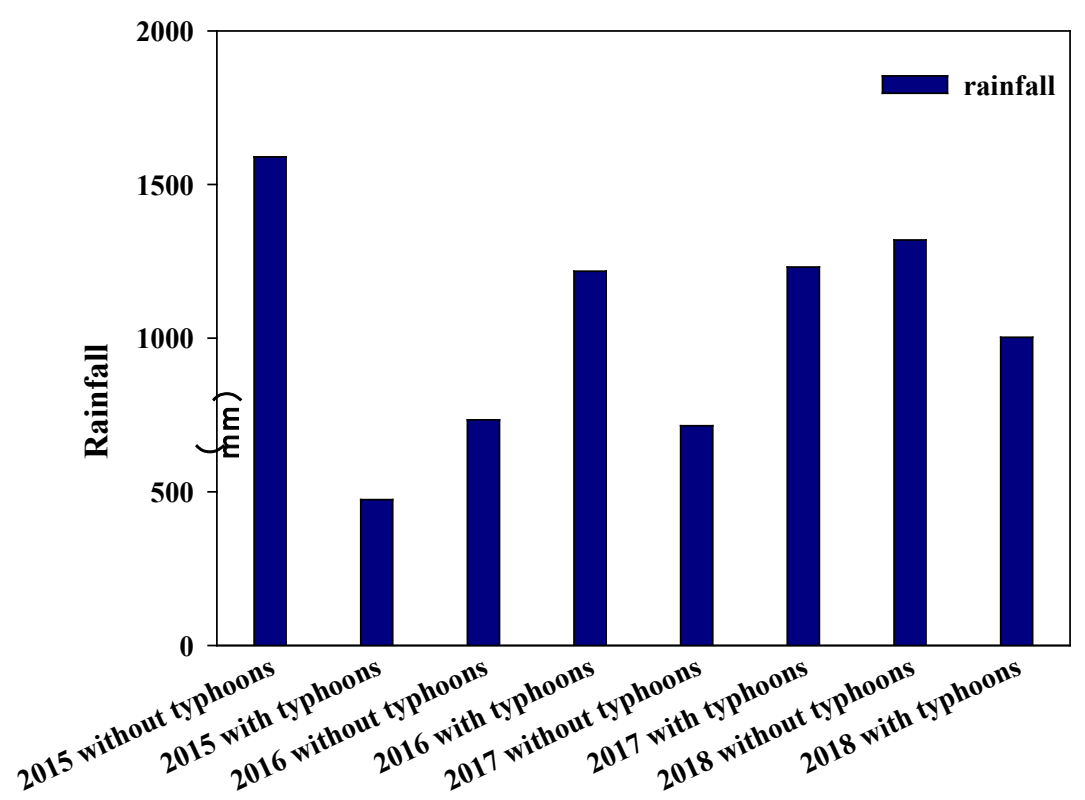

Fig. 4. Rainfall during typhoon and nontyphoon periods for various years.

Statistics, http://zhanjiang.gov.cn), creating large masses of dust in the air. Thus, the resuspension of dust had a crucial influence on $\mathrm{Ca}^{2+}$ concentrations in rainwater in Zhanjiang.

\subsection{Effects of Typhoons on Ionic Species}

Zhanjiang is frequently affected by typhoons, which influence the air quality and ion concentrations in rainwater (Yan et al., 2016). Therefore, May 2015 to April 2016 was defined as the 2015 period, that from May 2016 to April 2017 was defined as the 2016 period, that from May 2017 to April 2018 was defined as the 2017 period, and that from May 2018 to April 2019 was defined as the 2018 period. During the sampling periods, Zhanjiang, was indirectly or directly affected by 38 typhoons; Table S1 in supplemental material presents summary details of these typhoons. Generally, typhoons bring heavy precipitation. Typhoons contributed as much as $60 \%$ of the precipitation in Zhanjiang in 2016 and 2017 (Fig. 4). Among the study years, 2017 had the most (14) typhoons, and 2015 had the fewest (five). Only one super typhoon, Mujigae, directly affected Zhanjiang; Mujigae made landfall in Zhanjiang $\left(21.1^{\circ} \mathrm{N}, 110.6^{\circ} \mathrm{E}\right)$ on 2 October 2015, bringing heavy precipitation ( $336.05 \mathrm{~mm}$; Table S1 in supplemental material).

Fig. 5 presents the ionic species in precipitation during periods with or without typhoons for each study year. From 2016 to 2018, the levels of ions in rainwater in periods without typhoons were higher than those during typhoon periods. As previously mentioned, ionic species in rainwater were negatively influenced by seasonal variations in rainwater volumes. However, the study period of 2015 (Mujigae) was an exception (Figs. 3 and 5; Table S1 in supplemental material): The levels of $\mathrm{Cl}^{-}, \mathrm{Na}^{+}, \mathrm{Ca}^{2+}, \mathrm{SO}_{4}{ }^{2-}, \mathrm{Mg}^{2+}, \mathrm{F}^{-}$, and $\mathrm{K}^{+}$in rainwater during the 2015 typhoon period were $197.4,98.3,615.2,191.2,34.8,22.1$, and $20.0 \mu \mathrm{Eq} \mathrm{L}^{-1}$, respectively; in the 2015 period without

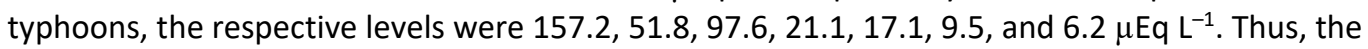
levels of ionic species were higher with typhoons than without in 2015 (Fig. 5). In 2015, the Ca ${ }^{2+}$ level during the typhoon period was six times higher than that during the nontyphoon period. These results contradict the finding that heavy rainfall can reduce ion concentrations in rainwater. Because Mujigae in 2015 was the strongest typhoon in terms of wind speed (with maximal and mean wind speeds of 50.0 and $47.4 \mathrm{~m} \mathrm{~s}^{-1}$, respectively) during the study period, the lack of a rainwater dilution effect may be related to wind speed.

Generally, typhoons bring high wind speeds. Ma et al. (2016) revealed that a high wind speed was conducive to pollutant dilution, leading to low aerosol levels and ion concentrations in rainwater. Table 4 presents a summary of all wind speed measurements during the study period. The average wind speed during the typhoon period in 2015 was markedly higher than that during other typhoon periods (Table 4). This finding implies that the strong wind brought by a typhoon 

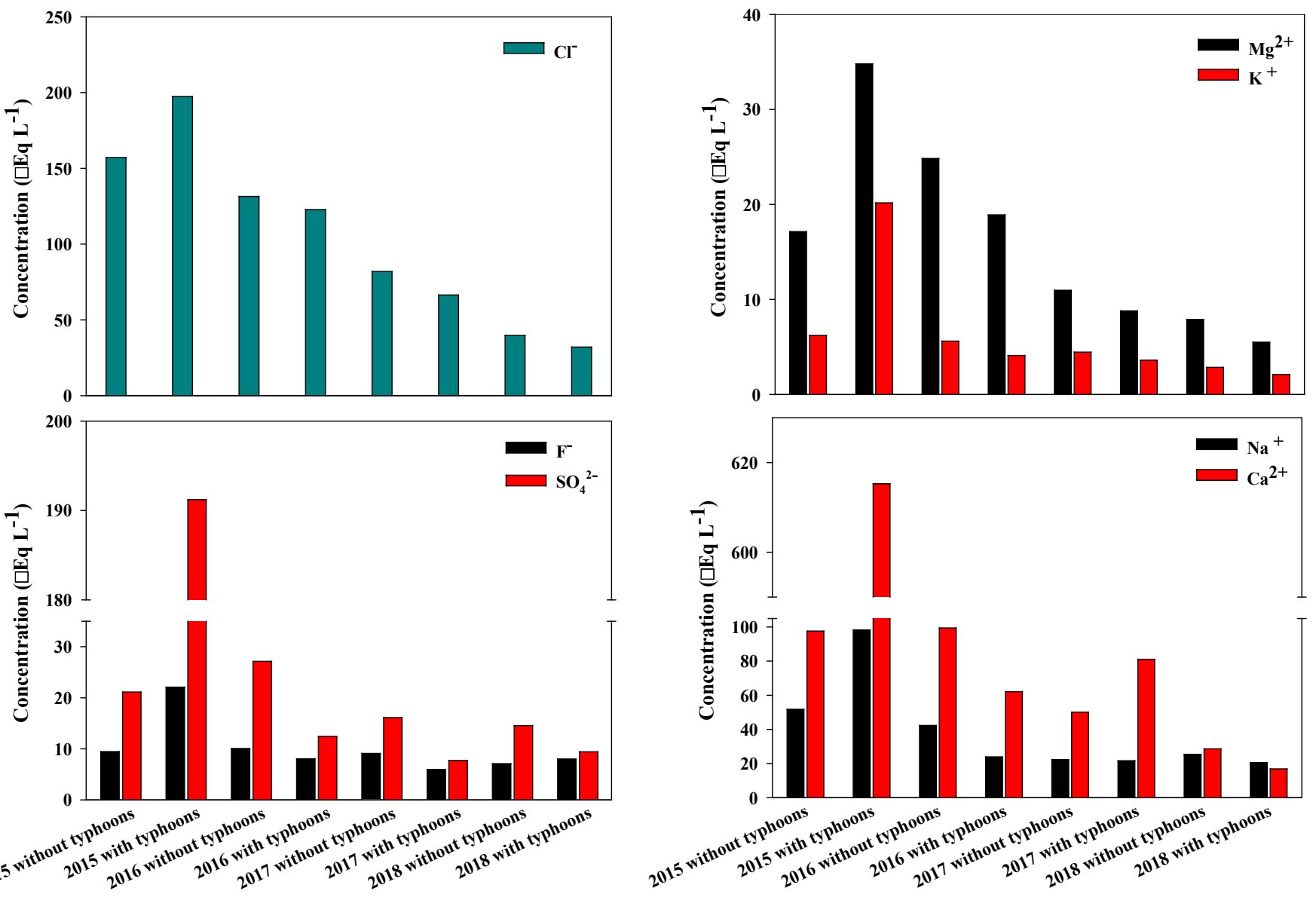

Fig. 5. Concentrations of $\mathrm{Cl}^{-}, \mathrm{Ca}^{2+}, \mathrm{Na}^{+}, \mathrm{SO}_{4}{ }^{2-}, \mathrm{NO}_{3}{ }^{-}, \mathrm{Mg}^{2+}, \mathrm{F}^{-}$, and $\mathrm{K}^{+}$during various periods.

Table 4. Average wind speed during typhoon and nontyphoon periods from 2015 to 2018.

\begin{tabular}{llll}
\hline \multirow{2}{*}{ Year } & \multirow{2}{*}{ Rainfall $(\mathrm{mm})$} & \multicolumn{2}{c}{ Wind speed $\left(\mathrm{m} \mathrm{s}^{-1}\right)$} \\
\cline { 3 - 4 } & & With typhoons & Without typhoons \\
\hline 2015 & 2131.54 & $\mathbf{1 6 . 0 8}$ & 11.47 \\
2016 & 1927.70 & 10.71 & 10.49 \\
2017 & 2039.58 & 12.84 & 10.52 \\
2018 & 2240.30 & 10.80 & 10.10 \\
\hline
\end{tabular}

Note: The bold text denotes super typhoon Mujigae.

can lead to low levels of ionic species in the atmosphere, and such species' levels are then diluted by rainfall. In the present study, the strongest typhoon (mean wind speed: $47.4 \mathrm{~m} \mathrm{~s}^{-1}$ ) was associated with high levels of ion species in rainwater; the $\mathrm{Cl}^{-}, \mathrm{Ca}^{2+}, \mathrm{Na}^{+}, \mathrm{SO}_{4}{ }^{2-}, \mathrm{Mg}^{2+}, \mathrm{F}^{-}$, and $\mathrm{K}^{+}$ levels in rainwater were 393, 1492, 192, 499, 72.7, 43.1, and $46.3 \mu \mathrm{Eq} \mathrm{L}^{-1}$, respectively (Fig. 5 and Table 4). This result was also observed in Xiamen, where high aerosol pollutant levels in the ambient air were linked to typhoons (Yan et al., 2016); such pollutants were then diluted by rainwater. The high ion concentrations in rainwater can be attributed to strong winds blowing ions from unpaved roads into the ambient atmosphere and then such ions being captured by rainfall, as suggested by the high concentrations of $\mathrm{Ca}^{2+}$ and $\mathrm{Mg}^{2+}$ during typhoon Mujigae period (Fig. 5); these ions are indicators of soil dust contributions (Xu et al., 2017).

However, during weak typhoon periods (2016, 2017 and 2018, the mean wind speed was $11.9 \mathrm{~m} \mathrm{~s}^{-1}$ ), the average concentrations of $\mathrm{Cl}^{-}, \mathrm{Ca}^{2+}, \mathrm{Na}^{+}, \mathrm{SO}_{4}{ }^{2-}, \mathrm{Mg}^{2+}, \mathrm{F}^{-}$, and $\mathrm{K}^{+}$in rainwater were $77.7,61.6,24.1,10.7,11.6,7.54$, and $3.52 \mu \mathrm{Eq} \mathrm{L}^{-1}$, respectively, significantly lower than those in periods without typhoons (mean wind speed: $10.65 \mathrm{~m} \mathrm{~s}^{-1}$ ) and the strong typhoon period of 2015 
(Fig. 5). The wind speed in weak typhoon periods was higher than that in periods without typhoons but significantly lower than that in strong typhoon periods. The results suggest that a slight increase in wind speed is conducive to pollutant dilution and subsequent rainfall dilution during weak typhoon periods. However, high wind speeds during strong typhoon periods can transport ions from roads into the air, and these ions can be captured by rainfall (Yan et al., 2016).

In conclusion, the effect of typhoons on the concentration of ions in rainwater mainly depends on wind speed. During strong (wind speeds $>47.4 \mathrm{~m} \mathrm{~s}^{-1}$ ) typhoon periods, winds can carry ions from continental sources to ambient air, and such ions are then captured by rainfall. During weak typhoon periods, the slight increase in wind speed is conducive to pollutant dilution, and rainfall subsequently causes further dilution. In this study, the concentrations of ions in rainwater were diluted by rainfall in nontyphoon periods.

\section{CONCLUSIONS}

From May 2015 to April 2019, rainwater samples from Zhanjiang were collected, and their chemical compositions (including levels of $\mathrm{Cl}^{-}, \mathrm{Ca}^{2+}, \mathrm{Na}^{+}, \mathrm{SO}_{4}{ }^{2-}, \mathrm{Mg}^{2+}, \mathrm{F}^{-}$, and $\mathrm{K}^{+}$) were analyzed. The highest VWM concentration in rainwater was that for $\mathrm{Cl}^{-}$, followed in order by the concentrations of $\mathrm{Ca}^{2+}, \mathrm{Na}^{+}, \mathrm{SO}_{4}{ }^{2-}, \mathrm{Mg}^{2+}, \mathrm{K}^{+}$, and the lowest for $\mathrm{F}^{-}$. Ion levels in rainwater from 2015 to 2018 were high during the dry seasons and low during the wet seasons, suggesting the dilution effect of rainfall. Ion concentrations in rainwater during strong typhoon periods, weak typhoon periods, and nontyphoon periods differed.

Strong winds $\left(>47.4 \mathrm{~m} \mathrm{~s}^{-1}\right)$ from a typhoon can increase levels of continentally sourced ions $\left(\mathrm{Ca}^{2+}\right.$ and $\left.\mathrm{Mg}^{2+}\right)$, which are then removed from the air by rainfall. By contrast, the weak winds (10.71-12.84 $\mathrm{m} \mathrm{s}^{-1}$ ) brought by weak typhoons dilute pollutants in ambient air, and such pollutants are subsequently further diluted by rainfall. Thus, compared with nontyphoon periods. strong typhoon periods result in higher ion concentrations in rainwater, and weak typhoon periods result in lower ion concentrations. These findings suggest that the chemical composition of rainwater changes with typhoon intensity, particularly wind speed, and thus provide new insight into the relationship between typhoons and ion levels in rainwater.

\section{ACKNOWLEDGMENTS}

This manuscript was edited by Wallace Academic Editing. This study was supported by the National Natural Science Foundation of China (U1901213), Guangdong Natural Science Foundation of China (2019B1515120066, 2016A030312004), and Scientific Research Start-Up Foundation of Shantou University (NTF20006), Project of Enhancing School with Innovation of Guangdong Ocean University (GDOU2016050260).

\section{SUPPLEMENTARY MATERIAL}

Supplementary material for this article can be found in the online version at https://doi. org/10.4209/aaqr.210210

\section{REFERENCES}

Al-Khashman, O. (2005a). Ionic composition of wet precipitation in the Petra Region, Jordan. Atmos. Res. 78, 1-12. https://doi.org/10.1016/j.atmosres.2005.02.003

Al-Khashman, O. (2005b). Study of chemical composition in wet atmospheric precipitation in Eshidiya area, Jordan. Atmos. Environ. 39, 6175-6183. https://doi.org/10.1016/j.atmosenv.20 05.06 .056

Al-Obaidy, A., Joshi H. (2006). Chemical composition of rainwater in a tropical urban area of northern India. Atmos. Environ. 40, 6886-6891. https://doi.org/10.1016/j.atmosenv.2005.01. 031

Baron, J., Denning, A. (1993). The influence of mountain meteorology on precipitation chemistry 
a low and high elevation of the Colorado Front Range, USA. Atmos. Environ. 27, 2337-2349. https://doi.org/10.1016/0960-1686(93)90402-K

Budhavant, K.B., Rao, P.S.P., Safai, P.D., Ah, K. (2009). Chemistry of monsoon and post-monsoon rains at a high altitude location, Sinhagad, India. Aerosol Air Qual. Res. 9, 65-79. https://doi.org/10.4209/aaqr.2008.07.0033

Cao, Y.Z., Wang, S., Zhang, G., Luo, J., Lu, S. (2009). Chemical characteristics of wet precipitation at an urban site of Guangzhou, South China. Atmos. Res. 94, 462-469. https://doi.org/10.101 6/j.atmosres.2009.07.004

Chen, F., Lao, Q., Jia, G., Chen, C., Zhu, Q., Zhou, X. (2019). Seasonal variations of nitrate dual isotopes in wet deposition in a tropical city in China. Atmos. Environ. 196, 1-9. https://doi.org/ 10.1016/j.atmosenv.2018.09.061

Chen, F., Lao, Q., Li, Z., Bian, P., Zhu, Q., Chen, C., Song, Z. (2020). Monthly variations of the nitrogen isotope of ammonium in wet deposition in a tropical city of South China. Aerosol Air Qual. Res. 20, 1062-1069. https://doi.org/10.4209/aaqr.2019.06.0303

Chen, F., Huang, C., Lao, Q., Zhang, S., Chen, C., Zhou, X., Lu, X., Zhu, Q. (2021). Typhoon control of precipitation dual isotopes in southern China and its palaeoenvironmental implications. J. Geophys. Res. 126, e2020JD034336. https://doi.org/10.1029/2020JD034336

Cheng, M., You, C. (2010). Sources of major ions and heavy metals in rainwater associated with typhoon events in southwestern Taiwan. J. Geochem. Explor. 105, 106-116. https://doi.org/1 0.1016/j.gexplo.2010.04.010

Dadashazar, H., Ma, L., Sorooshian, A. (2019). Sources of pollution and interrelationships between aerosol and precipitation chemistry at a central California site. Sci. Total Environ. 651, 1776-1787. https://doi.org/10.1016/j.scitotenv.2018.10.086

Fang, G., Lin, S., Chang, S., Chou, C. (2009). Effect of typhoon on atmospheric particulates in autumn in central Taiwan. Atmos. Environ. 43, 6039-6048. https://doi.org/10.1016/j.atmosen v.2009.08.033

Gioda, A., Mayol-Bracero, O., Scatena, F., Weathers, K., Mateus, V., McDowell, W. (2013). Chemical constituents in clouds and rainwater in the Puerto Rican rainforest: Potential sources and seasonal drivers. Atmos. Environ. 68, 208-220. https://doi.org/10.1016/j.atmosenv.2012.11.017

Gromping, A., Ostapczuk, P., Emons, H. (1997). Wet deposition in Germany: Long-term trends and the contribution of heavy metals. Chemosphere 34, 2227-2236. https://doi.org/10.1016/ S0045-6535(97)00080-5

Hideaki, S., Akira, T. (2005). Effect of typhoon on chemical composition of rainwater in Okinawa Island, Japan. Atmos. Environ. 39, 2879-2888. https://doi.org/10.1016/j.atmosenv.2004.12.043

Huang, D., Xu, Y., Peng, P., Zhang, H., Lan, J. (2009). Chemical composition and seasonal variation of acid deposition in Guangzhou, South China: comparison with precipitation in other major Chinese cities. Environ. Pollut. 157, 35-41. https://doi.org/10.1016/j.envpol.2008.08.001

Huang, K., Zhuang, G., Xu, C., Wang, Y., Tang, A. (2008a). The chemistry of the severe acidic precipitation in Shanghai, China. Atmos. Res. 89, 149-160. https://doi.org/10.1016/j.atmosre s.2008.01.006

Huang, Y., Wang, Y., Zhang, L. (2008b). Long-term trend of chemical composition of wet atmospheric precipitation during 1986-2006 at Shenzhen City, China. Atmos. Environ. 42, 3740-3750. https://doi.org/10.1016/j.atmosenv.2007.12.063

Jia, G., Chen, F. (2010). Monthly variations in nitrogen isotopes of ammonium and nitrate in wet deposition at Guangzhou, south China. Atmos. Environ. 44, 2309-2315. https://doi.org/10.101 6/j.atmosenv.2010.03.041

Keene, W., Pszenny A., Galloway J., Hawley, M. (1986). Sea salt correction and interpretation of constituent ratios in marine precipitation. J. Geophys. Res. 91, 6647-6658. https://doi.org/10. 1029/JD091iD06p06647

Khoon, S., Issabayeva, G., Lee, L. (2011). Measurement of rainwater chemical composition in Malaysia based on ion chromatography method. World Acad. Sci. Eng. Technol. 11, 161-168.

Kumar, P., Yadav, S., Kumar, A. (2014). Sources and processes governing rainwater chemistry in New Delhi, India. Nat. Hazards 74, 2147-2162. https://doi.org/10.1007/s11069-014-1295-0

Li, J., Li, R., Cui, L., Meng, Y., Fu, H. (2019). Spatial and temporal variation of inorganic ions in rainwater in Sichuan province from 2011 to 2016. Environ. Pollut. 254, 112941. https://doi.org/10.1016/j.envpol.2019.07.109 
Li, Y., Zhang, M., Shu, M., Ho, S., Liu, Z., Wang, X., Zhao, X. (2016). Chemical characteristics of rainwater in Sichuan basin, a case study of Ya'an. Environ. Sci. Pollut. Res. 23, 13088-13099. https://doi.org/10.1007/s11356-016-6363-4

Liu, Y.F. (2007). Analysis on characteristics and countermeasures of rainstorm flood and tidal disaster in Zhanjiang. Building Materials and Decoration. 7, 382-384. (in Chinese with English Abstract)

Liyandeniya, A., Deeyamulla, M., Priyantha, N. (2020). Source apportionment of rainwater chemical composition in wet precipitation at Kelaniya in Sri Lanka. Air Qual. Atmos. Health 13, 1497-1504. https://doi.org/10.1007/s11869-020-00903-w

Lu, P., Han, G., Wu, Q. (2017). Chemical characteristics of rainwater in karst rural areas, Guizhou Province, Southwest China. Acta. Geochim. 36, 572-576. https://doi.org/10.1007/s11631-0170238-3

Lu, X., Li, L., Li, N., Yang, G., Luo, D., Chen, J. (2011). Chemical characteristics of spring rainwater of Xi'an city, NW China. Atmos. Environ. 45, 5058-5063. https://doi.org/10.1016/j.atmosenv.2 011.06 .026

Ma, L., Li, M., Zhang, H., Li, L., Huang, Z., Gao, W., Chen, D., Fu, Z., Nian, H., Zou, L., Chai, F., Zhou, Z. (2016). Comparative analysis of chemical composition and sources of aerosol particles in urban Beijing during clear, hazy, and dusty days using single particle aerosol mass spectrometry. J. Cleaner Prod. 112, 1319-1329. https://doi.org/10.1016/j.jclepro.2015.04.054

MacDonald, A.B., Dadashazar, H., Chuang, P.Y., Crosbie, E., Wang, H., Wang, Z., Jonsson, H.H., Flagan, R.C., Seinfeld, J.H., Sorooshian, A. (2018). Characteristic vertical profiles of cloud water composition in marine stratocumulus clouds and relationships with precipitation. J. Geophys. Res. 123, 3704-3723. https://doi.org/10.1002/2017JD027900

Mehr, M.R., Behnam, K., Armin, S. (2019). Influence of natural and urban emissions on rainwater chemistry at a southwestern Iran coastal site. Sci. Total Environ. 668, 1213-1221. https://doi.org/10.1016/j.scitotenv.2019.03.082

Migliavacca, D., Teixeira, E.C., Wiegand, F., Machado, A., Sanchez, J. (2005). Atmospheric precipitation and chemical composition of an urban site, Guaíba hydrographic basin, Brazil. Atmos. Environ. 39, 1829-1844. https://doi.org/10.1016/j.atmosenv.2004.12.005

Mouli, P., Mohan, S., Reddy, S. (2005). Rainwater chemistry at a regional representative urban site: Influence of terrestrial sources on ionic composition. Atmos. Environ. 39, 999-1008. https://doi.org/10.1016/j.atmosenv.2004.10.036

Pye, H.O., Nenes, A., Alexander, B., Ault, A.P., Barth, M.C., Clegg, S.L., Zuend, A. (2020). The acidity of atmospheric particles and clouds. Atmos. Chem. Phys. 20, 4809-4888. https://doi.org/10.5 194/acp-20-4809-2020

Qiao, X., Xiao, W., Jaffe, D., Kota, S., Ying, Q., Tang, Y. (2015). Atmospheric wet deposition of sulfur and nitrogen in Jiuzhaigou national nature reserve, Sichuan province, China. Sci. Total Environ. 511, 28-36. https://doi.org/10.1016/j.scitotenv.2014.12.028

Qin, R., Khakzad, N., Zhu, J. (2020). An overview of the impact of Hurricane Harvey on chemical and process facilities in Texas. Int. J. Disaster Risk Reduct. 45, 101453. https://doi.org/10.1016/ j.ijdrr.2019.101453

Qu, R., Han, G. (2021). A critical review of the variation in rainwater acidity in 24 Chinese cities during 1982-2018. Elementa-Sci. Anthrop. 9, 00142. https://doi.org/10.1525/elementa.2021. 00142

Rastegari, M., Keshavarzi, B., Sorooshian, A. (2019). Influence of natural and urban emissions on rainwater chemistry at a southwestern Iran coastal site. Sci. Total Environ. 668, 1213-1221. https://doi.org/10.1016/j.scitotenv.2019.03.082

Sakihama, H., Tokuyama, A. (2005). Effect of typhoon on chemical composition of rainwater in Okinawa Island. Jpn. Atmos. Environ. 39, 2879-2888. https://doi.org/10.1016/j.atmosenv.200 4.12.043

Sorooshian, A., Shingler, T., Harpold, A., Feagles, C.W., Meixner, T., Brooks, P.D. 2013. Aerosol and precipitation chemistry in the southwestern United States: Spatiotemporal trends and interrelationships. Atmos. Chem. Phys. 13, 7361-7379. https://doi.org/10.5194/acp-13-73612013

Souri, A.H., Choi, Y., Kodros, J.K., Jung, J., Shpund, J., Pierce, J.R., Lynn, B.H., Khain, A., Chance, K. (2020). Response of Hurricane Harvey's rainfall to anthropogenic aerosols: A sensitivity study 
based on spectral bin microphysics with simulated aerosols. Atmos. Res. 242, 104965. https://doi.org/10.1016/j.atmosres.2020.104965

Spracklen, D.V., Baker, J.C.A., Garcia-Carreras, L., Marsham, J.H. (2018). The effects of tropical vegetation on rainfall. Annu. Rev. Environ. Resour. 43, 193-218. https://doi.org/10.1146/annu rev-environ-102017-030136

Su, N., Yang, S., Xie, X. (2018). Typhoon-enhanced silicon and nitrogen exports in a mountainous catchment. J. Geophys. Res. 123, 2270-2286. https://doi.org/10.1029/2018JG004389

Tang, X., Zhang, Y., Shao, M. (2006). Atmospheric environment chemistry 2nd ed. Higher Education Press, Beijing.

Valappil, N., Viswanathan, P., Hamza, V. (2020). Chemical characteristics of rainwater in the tropical rainforest region in northwestern Borneo. Environ. Sci. Pollut. Res. 27, 36994-37010. https://doi.org/10.1007/s11356-020-09542-1

Xing, J., Song, J., Yuan, H., Li, X., Li, N., Duan, L., Qu, B., Wang, Q., Kang, X. (2017). Chemical characteristics, deposition fluxes and source apportionment of precipitation components in the Jiaozhou Bay, North China. Atmos. Res. 190, 10-20. https://doi.org/10.1016/j.atmosres.20 17.02.001

Xu, J., Xu, M., Snape, C., He, J., Behera, S., Xu, H., Ji, D., Wang, C., Yu, H., Xiao, H., Jiang, Y., Qi, B., Du, R. (2017). Temporal and spatial variation in major ion chemistry and source identification of secondary inorganic aerosols in Northern Zhejiang Province, China. Chemosphere 179, 316330. https://doi.org/10.1016/j.chemosphere.2017.03.119

$\mathrm{Xu}, \mathrm{Z}$., Han, G. (2009). Chemical and strontium isotope characterization of rainwater in Beijing, China. Atmos. Environ. 43, 1954-1961. https://doi.org/10.1016/j.atmosenv.2009.01.010

Xu, Z., Li, Y., Tang, Y., Han, G. (2009). Chemical and strontium isotope characterization of rainwater at an urban site in Loess Plateau, Northwest China. Atmos. Res. 94, 481-490. https://doi.org/10.1016/j.atmosres.2009.07.005

Yan, J., Chen, L., Lin, Q., Zhao, S., Zhang, M. (2016). Effect of typhoon on atmospheric aerosol particle pollutants accumulation over Xiamen, China. Chemosphere 159, 244-255. https://doi.org/10.1016/j.chemosphere.2016.06.006

Zhou, X., Xu, Z., Liu, W., Wu, Y., Zhao, T., Jiang, H., Zhang, X., Zhang, J., Zhou, L., Wang, Y. (2019). Chemical composition of precipitation in Shenzhen, a coastal mega-city in South China: Influence of urbanization and anthropogenic activities on acidity and ionic composition. Sci. Total Environ. 662, 218-226. https://doi.org/10.1016/j.scitotenv.2019.01.096

Zhou, X., Chen, C., Chen, F., Song, Z. (2021). Changes in net anthropogenic nitrogen input in the watershed region of Zhanjiang Bay in south China from 1978 to 2018. Environ. Dev. Sustain. 23, 17201-17219. https://doi.org/10.1007/s10668-021-01335-x 